\title{
Controversial Theories on the Death Penalty
}

\author{
Laura Zavatta \\ Department of Law, Economics, Management and Quantitative Methods (D.E.M.M.), Benevento, Italy \\ Email:1zavatta@unisannio.it
}

How to cite this paper: Zavatta, L. (2017). Controversial Theories on the Death Penalty. Beijing Law Review, 8, 212-225. https://doi.org/10.4236/blr.2017.82012

Received: November 16, 2016

Accepted: June 26, 2017

Published: June 29, 2017

Copyright $\odot 2017$ by author and Scientific Research Publishing Inc. This work is licensed under the Creative Commons Attribution International License (CC BY 4.0).

http://creativecommons.org/licenses/by/4.0/

\begin{abstract}
The question of the right to carry firearms, but especially abolishing the death penalty, had a tremendous impact on the intellectual and political community of the whole world with the ideas of Beccaria that stimulated the urgency also of the founding fathers of the various American colonies to give life to the new Constitutions reforming the existing criminal law and proceeding to the elimination of the capital punishment in many cases. However, after about two hundred and fifty years, the death penalty, which seemed destined to be abolished by the end of the eighteenth century, is still in use in the American legal system and a great subject of debate, despite several Supreme Court rulings. Even in Italy, the period that preceded its unification, was marked by a return to the past with regard to the penal system and the conception of the death penalty. Similarly, although the European continent is "death penalty free", and the modern criminal law is generally constituted from its rejection of torture, in recent years, with the escalation of acts of terrorism and global tension, it seems to reoccur the relationship between torture and right, as if it was a reconciliation between two old friends and a strategy to re-legalize torture.
\end{abstract}

\section{Keywords}

Death Penalty Criminal Law Firearms License Torture and Right

\section{Introduction}

The legal experience on the death penalty is marked by the thought of Beccaria, who revolutionized criminal law, arguing with rigor on the thesis that the State has no right to apply torture and death penalty. Capital punishment is considered by Beccaria an incivility instrument managed by the State, as a real legalized revenge, although it should be noted that the tradition of Western thought has been for centuries in favour of it. A declaration in favour of the death penalty was made by great philosophers such as Plato, Kant, Hegel, Schopenhauer. Plato in the Laws, and the two leading philosophers of the time, Kant and Hegel, the one before, the other after the French Revolution, advocated a strict retributive 
theory of punishment and came to the conclusion that the death penalty was even a duty. Kant adhered to the ethical-legal view of penalty: its function is not to prevent crimes but to do justice, that is, to make sure that it was determined with a perfect correspondence between crime and punishment. We are dealing, in this case, with the concept of justice, which the ancients called "corrective equality". According to this view, the obligation to impose death penalty belongs to the State and is not a hypothetical imperative but a categorical imperative, based on the means-end relationship. If a criminal has killed, he has to die. "There is no substitute, no reprieve, which will satisfy justice. There is no possible comparison between a life, however painful, and death, and, therefore, there is no payment or other consideration between the crime and the punishment, except in death, legally inflicted on the criminal, stripping it, however, of all malice that could disturb humanity"1. Hegel went further. After challenging the argument of social contract, very important for Beccaria, denying that the State can be born from a contract, he argued that not only the offender shall be punished by a penalty corresponding to the crime committed, but he has even the right to be punished since only punishment can redeem him, recognizing him a rational being. With the penalty the offender is "honored", said Hegel. In addition to paragraph 100 of Elements of the Philosophy of Rights, in which is the reference to Beccaria, Hegel acknowledged that the work of the Italian jurist had the effect of reducing the number of death sentences. "The Beccaria effort-writes Hegel-for the death penalty's abolition, produced beneficial effects; and although neither Joseph II nor the French is able to succeed to the total abolition of it, however, thanks to the thought of the Marquis is beginning to be recognized which crimes are punishable and which not"2. As for Schopenhauer, you may remember his famous appeal. "To those who would abolish it, we must reply: 'It's necessary to abolish before the murder from the world then you will also abolish the death penalty"'3.

\section{The Position of Robespierre}

With the advent of the Enlightenment, the legitimacy of the death penalty, extreme and cruel, began to be more and more challenged, and in this atmosphere Cesare Beccaria, the first resolute supporter of the abolitionist cause, was a huge success with the publication of the book Dei delitti e delle pene $e^{4}$. While the major philosophers of the time continued to substantiate the legitimacy of the death penalty, in addition to the Marquis, a major supporter of its abolition was Robespierre, as stated in the famous speech to the Constituent Assembly, in May 1791. The amazing thing is that Robespierre was the man who would go down in history, in the era of the Restoration-at the same time in which Hegel was ${ }^{1}$ See the second part of the Doctrine of Right dedicated to the Public Right. Kant, I. (1956). Political Writings and the history and philosophy of law, ed. by G. Solariand G. Vidari, 522. Torino: Utet. ${ }^{2}$ Hegel, G. W. F. (1954). Elements of Philosophy of Right, 327. Roma: Laterza. ${ }^{3}$ Schopenhauer, A. (1999). The art of insulting, ed. by F. Volpi, 27. Milano: Adelphi.

${ }^{4}$ The work was printed for the first time in 1764 in Livorno by Marco Coltellini. See Cattaneo, M.A. (1968). Freedom and virtue in the political thinking of Robespierre. Milano: Editorial Cisalpino Institute. 
composing his work-as the most representative of the revolutionary assassination and indiscriminate climate of fear, in which, in the end, he himself was a victim. Robespierre's speech must be remembered because, from the point of view of his argumentation, plays one of the most persuasive dissuasions of the death penalty. He refuted first of all the argument of deterritio, proving that the death penalty wasn't a stronger deterrent than other punishments, as already attested to Montesquieu. The death penalty was almost ritual in Japan, so that the Country of the Rising Sun, at that time, was condemned by all for atrocious pains perpetrated on offenders as land considered an immense den of criminals. Robespierre also developed the thesis founded on the consent of the people, the one based on justice, and finally, the issue of irreversibility of judicial errors. His reasoning supported the principle that the mildness of punishments, where the influence of Beccaria thought is evident, was proof of civilization, while the cruelty of punishments characterized the barbarous nations, such as Japan. Therefore, probably the most famous and insightful follower of Beccaria was Robespierre, that in the conclusion of his speech said: "Il faut croire che le people doux, sensibile, generaux qui habite la France, et dont toutes les vertus vont etre dèveloppeès par le règime de la libertè, traitela avec humanitè les coupables, et convenir que P expèrience, la sapesse vous permettente de consacrer les principes sur lesquels s'appuie la motion que je fais que la peine de mort soit abolie". The premise from which Beccaria took the moves for his argument is only the intimidating function of punishment. "The purpose of punishment is nothing less than to prevent the offender does any more damage to his countrymen and to remove others from making of equals"s.

\section{The "Little Book"}

The Marquis fought with force and lucidity judicial barbarism of the old regime and the depravity of existing social patterns, concentrating its invective against secret accusations, infamous use of torture, the injustice of the punishment method, the death penalty. The "little book" Dei delitti e delle pene was a resounding success thanks to favourable reception reserved to it by Voltaire, the extraordinary French thinker, already famous in the homeland of the Enlightenment, who favoured the emergence of a fervent debate around the question of the death penalty. Was enacted, thus, the first criminal law that led to its abolition, the law of Tuscany of 1786 when, after a series of notes in which it was gave large space to the corrective capacity of punishment ("the correction of the offender, son also the society and the state"), it is claimed "to see an end to the death penalty against any offender, present or future" ${ }^{36}$. Remarkable was the echo that this debate was also in Russia of Catherine II, who, after the release of the book of Beccaria, wrote in the celebrated "Instruction" of 1765: "the experience of all ages proves that the death penalty has not ever made a better nation" be${ }^{5}$ Beccaria, C. (1965). Dei delitti e delle pene, ed. by F. Venturi, 31. Torino: Einaudi. This book contains, in addition to the famous text, documents of its extraordinary fortune in Italy and Europe in the eighteenth century.

${ }^{6}$ Venturi, F. (2009). Settecento Riformatore. Vol. I: Da Muratori a Beccaria, 274, 646. Milano: Einaudi. The text of the "Reform of the Tuscan criminal law" of November 30, Venturi, 1786. 
fore quoting a phrase that is inspired by a famous passage of book Dei delitti $e$ delle pene. "Therefore, if it is shown that the death of a citizen is neither useful nor necessary, I will have won the cause of humanity" (Venturi, 2009) ${ }^{7}$. The thought of Beccaria had a tremendous impact on the intellectual and political community, and his theories are the ones still used today by the world and on which raises his banner the same Amnesty International. The problem of criminal law came to prominence as a topical issue whose solution could not be entrusted only to "technicals". So, prestigious Philosophers, which were the authors of the Encyclopédie, toga men and princes, showed themselves willing and interested to the thesis of the Marquis of Milan. Within a few years, Dei delitti e delle pene was translated and printed not only several times in France, England, Germany, Austria, Spain, Sweden, but also in America, it became the focus of academic discussions and cultural circles.

\subsection{The Influence of Beccaria in North America}

Even North America, where the spirit of rationalism and Humanitarian Enlightenment had found a highly fertile ground, as claimed by Maestro in his essay on "pioneer" of the abolitionist cause, was one of the places where Beccaria gained popularity very soon. The first English translation of Dei delitti e delle pene was published in London and Dublin in 1767, three years after the onset of the first Italian edition, and in the American colonies, the Marquis quickly became one of the most famous writers of Europe. A test of his popularity in America came in the trial held in 1770 against the British soldiers involved in the so-called "Boston Massacre". The soldiers were defended by John Adams, the future president of the United States, who was then a young lawyer, who, in the face of a hostile court, in a crowded room of people resentful charges, began his speech in defense of soldiers with words of Beccaria. "May it please your honors, and you, gentlemen of the jury. I am for the prisoners at the bar, and shall apologize for it only in the words of the Marquis Beccaria: if I can but be the instrument of preserving one life, his blessing and tears of transport shall be a sufficient consolation to me for the contempt of all mankind"s. Adams led the defense with such skill and eloquence that, in the end, none of the soldiers was accused of intentional murder. The two soldiers convicted of manslaughter received only symbolic punishment. That night, after the verdict, Adams mentioned again Beccaria in his diary'. Meanwhile, more copies of his book came to

\footnotetext{
${ }^{7}$ From the sixth "Instruction" reported in the Legislation Reform. In the preface, Venturi speaks of Catherine II as a "plagiaristic" faithful to Cesare Beccaria.

${ }^{8}$ Kidder, F. (1870). History of the Boston Massacre, 232. Albany: Joel Munsell. See Maestro, M. (1973). A Pioneer for the Abolition of Capital Punishment: Cesare Beccaria, Journal of the History of Ideas 34 (3): 463-468. On the night of March 5, 1770, a group of "kids freedom" attacked the British sentries at the customs of the port of Boston. After a scuffle one of the soldiers was knocked to the ground. In the confusion that followed some soldiers opened fire on the crowd, killing five people. American propagandists defined once this event the "Boston Massacre", and mounted in the city a great anger. Brought to trial before a jury of Bostonians, the soldiers involved in the incident were defended by John Adams.

${ }^{9}$ Adams, J. (1856). The Works of John Adams, 238-239. Boston: Little, Brown. See Funston, R. J. (1976).Cesare Beccaria and The American Founding Father. Italian Americana 3 (1): pp. 72-92.
} 
America from Europe, and in 1773, the Rivington New York publisher announced plans to publish his edition of book Dei delitti e delle pene. The work, with Voltaire's comment, was published in Charleston, and soon after another edition appeared in Philadelphia. The revolutionary war began then, and the influence of Beccaria thought stimulated the urgency of the founding fathers of the various American colonies to give life to the new Constitutions reforming the existing criminal law and proceeding to the elimination of the death penalty in many cases which had already been prescribed (Funston, 1976) ${ }^{10}$. In 1776, the founder of Pennsylvania, William Penn, determined to reform the penal system with punishments less cruel and more proportionate to the different degrees of crime, limited the death penalty to only four crimes: murder, rape, arson and treason. A further step was taken eight years later, with the adoption of an Act for the Better Preventing of Crimes and for Abolishing the Punishment of Death in Certain Cases, to prevent crimes and delete the extreme condemnation in various cases. However, the abolition of the death penalty was not total, and several prominent citizens of Pennsylvania tried to work towards this ultimate goal. One of the most important proponents of this attempt was Benjamin Rush, a professor of clinical medicine at the University of Pennsylvania, famous for being one of the signers of the Declaration of Independence. In 1792, Dr. Rush published an essay in which he argued that "Marquis Beccaria has established a link between the abolition of capital punishment and the order and happiness of society". On the objection that the Bible approves the death penalty, Dr. Rush responded by analysing various biblical passages that, according to his interpretation, if they tested exactly, instead they reveal a different point of view ${ }^{11}$. Another writer who declared himself in favour of the complete abolition of capital punishment was Robert J. Turnbull. In his book, $A$ Visit to the Prison in Philadelphia, Turnbull used different arguments untouched by Dr. Rush, including the positive results obtained in Tuscany thanks to the abolition of the death penalty.

\subsection{The Right to Carry Firearms and the Return of Torture}

However, the legislature of Pennsylvania refused to take the final step and failed to pass a law for the definite death penalty abolition in his State. Among the admirers of Beccaria in America can be counted also the first citizen of Virginia, Thomas Jefferson. In his book there are no less than twenty-six excerpts from the essay of the Marquis, all quoted in the Italian language, including one in which Beccaria attacks, for the first time, the laws that prohibit the right to carry firearms, arguing that such laws are only for the benefit of criminals and that when firearms are considered outlawed, only the outlaws have guns, thesis that continues to raise a very intense debate in the United States. The Second

${ }^{10}$ The influence of the Marquis thought in America, and particularly on the Bill of Rights, goes far beyond the Eighth Amendment prohibition against cruel and unusual punishment, and also extends to the Fifth and Sixth.

${ }^{11}$ Rush, B. (1792). Considerations of the Injustice and Impolicy of punishing Murder by Death, $3 \mathrm{ff}$. Philadelphia: Mathew Carey. 
Amendment to the Constitution, in fact, which enshrines the right to carry firearms, is still considered inviolable, as notes Mastrolilli, although it is a remnant of the past as unwritten rule that has more than two centuries. In that period you lived in another situation, in another America. "The country had just been joined by a revolution and saw the direct involvement of citizens in bloody acts of war so as to feel the need to have armed militias among civilians. This is a warlike situation, that in the United States no longer exists, for the disappearance of the decisive historical factor. The only surviving vestige is the existence of a strong lobby of arms manufacturers with an interest in maintaining the status quo for his business". The lobby of the arms manufacturers, as continues Mastrolilli, very strong and rooted in various American states, influences the political with the funding that it gives and the votes that it controls. The politicians have no interest to cause their irritation, so the debate remains firm and every initiative is blocked ${ }^{12}$. Thomas Jefferson, more than two hundred years ago, was very impressed by the affirmation of Beccaria and brought it in his Commonplace Book $^{13}$. Jefferson knew, however, that could not push too far and not strove to abolish the death penalty completely. The first citizen of Virginia obtained merely to keep it as punishment for treason and murder and called for a solution of a just balance between offenses and penalties ${ }^{14}$. The bill provoked strong opposition and passed only after a long and difficult discussion. In any case, under the influence of the decisions taken by the states of Pennsylvania and Virginia, the criminal law became the subject of debate in other states of the American Republic. Even the Ohio state took an important decision when it passed a law which applied the death penalty only to intentional murder. An attitude of greater respect for human life was indeed emerging, and Beccaria had largely the merit of the substantial reduction in the number of executions across America. After about two and a half centuries, however, the death penalty, which seemed destined to be abolished by the end of the eighteenth century, is still in use in the American legal system and it's a great subject of debate, despite several Supreme Court rulings. Opponents of capital punishment still use the arguments presented so eloquently by Beccaria, but his name is now rarely mentioned and Americans today seem to ignore "the precious gift" made to the

\footnotetext{
${ }^{12}$ See Sanfrancesco website. http://www.sanfrancescopatronoditalia.it/17717.

${ }^{13}$ Jefferson, in the proposal for the Virginia Constitution, writes that "no freeman has prevented the use of weapons [within their lands or homes]" proving his predilection for Beccaria. However, the main architect of the Virginia Declaration of Rights and its Constitution wasn't Thomas Jefferson, but George Mason, that instead declared himself in favor of the justness of a well-regulated militia, in terms reminiscent of James Burgh, not Beccaria. Cornell, S. (2004). A New Paradigm for the Second Amendment. Law and History Review 22 (1): 161-167. Chinard, G. (1926). The Commonplace Book of Thomas Jefferson, 314. Baltimore: Johns Hopkins Press. On the influence of Beccaria in America, see also Lundberg D. \& May, H. (1976) “The Enlightened Reader In America”, American Quarterly, 28, pp. 262-293, and Lutz, D. S. 1984. The Relative Influence of European Writers on Late Eighteenth-Century American Political Thought. American Political Science Review 78: 189-97.

${ }^{14}$ Turnbull, R. J. (1797). A Visit to the Philadelphia Prison, 6 ff. London: J. Philips \& Son; Chinard, G. (1926). The Commonplace Book of Thomas Jefferson, 298-316. Baltimore: Johns Hopkins Press; Jefferson, T. (1904). The Writings of Thomas Jefferson, $67 \mathrm{ff}, 218 \mathrm{ff}$. Washington: T. Jefferson Memorial Association.
} 
world of his immortal work that inspired the movement of penal reforms in the USA when this country was still a young Republic (Maestro, 1973). Similarly, the modern criminal law is constituted from its rejection of torture, as argues La Torre, but in recent years it seems to reoccur the relationship between torture and right as if it was a reconciliation between two old friends and a strategy to re-legalize torture. We are seeing, in fact, a kind of return of torture within the walls of codes, decrees and judgments ${ }^{15}$. A return that has various causes or origins. The first derives from the tragic situation of the State of Israel, to heal that and acts of heinous terrorism, it seems that it's necessary to obtain information also by mobilizing the instrument of torture. The second cause of this regressive history derives from the attack on the Twin Towers on September 11, 2001, for which the use of torture would be applicable under the justification of the state of necessity. But, as Michael Ignatieff warns, "It is difficult to think honestly about torture"16 even though it is considered a lesser evil. Certainly the attitude of a lesser evil-as suggested by Hannah Arendt-leads people to resort to lesser evil, as a justification, forgetting soon, that though minor, is always bad; and the one who accepts and defends and practice it, cannot be exempted from blame for this. However, Article 3 of the European Convention on Human Rights states that in no case is it possible to deploy the instrument of torture or inhuman and degrading treatment. This is reaffirmed in Article 2 of the UN Convention of 1987. It follows that is unlikely that the application of torture can govern themselves according to some criterion of proportionality ${ }^{17}$.

\subsection{The Reason of the Injustice of the Death Penalty}

Beccaria insisted with his abolitionist arguments on the need of the sweetness of penalty because the atrocity of punishment is contrary to the principles of humanity, it violates the principle of proportionality and, above all, is ineffective from a utilitarian point of view. The death penalty is absurd and useless because though it seems a valid tool to protect the community, it doesn't absolve to one of its main purposes: it fails, i.e., into correct the criminal, but proceeds only to its elimination. The death penalty is all the more unlawful as it has no basis in the original contract in which the company was formed. In renunciation of a small portion of freedom which all citizens were willing to sign to give birth to the "society", could not be certainly including the waiver of the maximum of all the goods that every man possesses, namely life ${ }^{18}$. The retributive justice must, therefore, stop in front of the lives of individual subscribers of the social contract. Another reason of the injustice of the death penalty lies in the grounds of the Church doctrine. If the Church believes that the one who took his own life

${ }^{15}$ La Torre, M. (2009). Derecho y fuerza, Jueces para la democrazia, 66: 97-124.

${ }^{16}$ Ignatieff, M. (2004). The lesser Evil. Political Ethics in an Age of Terror. Princeton: Princeton University Press.

${ }^{17}$ La Torre, M. (2015). Amicizie pericolose. Tortura e diritto. Filosofia del diritto, 2: 271-282; Frankenberg, G. (2008). Torture and Taboo. An Essay Comparing Paradigms of Organized Cruelty. The American Journal of Comparative of Law 56: 403-422; Grimm, D. (2004). Esgeht ums Prinzip. Frankfurter: Frankfurter Allgemeiner Zeitung.

${ }^{18}$ Beccaria, C. (1764). Dei delitti e delle pene, 80-81. Milano: Edizione Nuovissima. 
by suicide committed a mortal sin, the more any man cannot give this power to others. The punishments are fair only if perform their primary purpose: to redeem the guilty and reinsert it into the welfare state. The death penalty, instead, besides being unjust, is neither useful nor necessary, since it was found that its deterrent power is less effective than a perpetual imprisonment; the fear in the condemned, in fact, is aroused not by the intensity of punishment, but by its extension in time. The maximum deterrent effect doesn't come from a terrible but passenger spectacle of death, which is the killing of a criminal, but from the long and laboured vision of a man without freedom, who became like a beast from service, who pays for his efforts the company that offended (Beccaria, 1764). This is the deterrent that negatively affects the determination to commit a crime.

\section{A Position in Favour of the Death Penalty: Raffaele Garofalo}

A century after the work of Beccaria, even in Italy, in the period of history that preceded its unification, was marked by a return to the past with regard to the penal system and the conception of the death penalty. There was a real exaltation of the throne and the Executioner ${ }^{19}$. Raffaele Garofalo, for example, recognizing that "natura non facit saltum", argued that the moral anomaly, although hardly recognizable, is among the lowest rungs of the ladder of crime. The famous jurist, therefore, referring to the criminal anthropology of Lombroso thought, believed that a nature tending to evil could be framed in the scale of the crime, accepting the hypothesis of congenital inheritance to commit crimes ${ }^{20}$. The offender, therefore, had to be considered as organically constituted by a permanent psychic anomaly ${ }^{21}$. The lack of morality and of the common feeling of piety and probity, which characterizes the higher human races making them suitable for life in society (Garofalo, 1885) ${ }^{22}$, induces the criminal to commit the crime, which, as claimed by Lombroso, is an event that is a direct threat to the company's survival (Garofalo, 1885) ${ }^{23}$. Consequently, the criminal is a person unfit to live in the community, because its moral is so far from that of the society in which it is inserted that disturbs the conscience severely. Garofalo repeatedly faced the problem of the spread of crime and of the weakness of the Italian repressive system, with specific reference to habitual crime and offenders with mental disorders. In 1925 Garofalo joined the National Fascist Party, and when Minister Rocco addressed the issue of criminal repression in his speech to the House, on 27 May of that year, quoted words of Garofalo on the budget of justice where it was asked to embitter the too ineffective combating crime, and to

${ }^{19}$ Tessitore, G. (2003). Fascismo e pena di morte, 75. Milano: Franco Angeli Editore.

${ }^{20}$ Taken from the Bulletin. 2007. "Foro Romano" 3-4: 665-6.

${ }^{21}$ Garofalo, R. (1885). Criminology. Study on crime, its causes and the means of repression, 4, 31, 50, 156, 200, 251 and 422-423. Torino: F. lliBocca.

${ }^{22}$ The allusion to the superior races is considered essential to avoid confusion with wild populations wich are free of these "altruistic instincts" that are considered fundamental in the more developed societies.

${ }^{23}$ Garofalo says that the concept of crime wasn't coined by legislators but belongs to the common language. It's the man who created the crime, so it's natural, because inherent in the very nature of man. 
look into the matter of habitual offenders and of those insane. Following, Garofalo was rapporteur of the law for the defense of the State that reintroduced the death penalty for political attacks, which was a real anticipation of its re-introduction in the code, according to the intentions of the Keeper of the Seals ${ }^{24}$. As Raffaele Garofalo says in Criminology. Study on crime, its causes and the means of repression, you must see in the repeated and habitual offender a real enemy of society $y^{25}$. An enemy in front of which the company itself has to react, trying, by all means, to expel him from within ${ }^{26}$. The criminal punishment should consist of an activity of distinction, in a separation of the criminal universe in two areas: on one hand the irredeemable delinquent, the sworn enemy of humanity, the one who leads a sort of fiercely predatory life $^{27}$; on the other the offender able to provide some guarantee of re-socialization, bearer of "moral sentiments that can do that still adhere to the human species" which we must strive to facilitate his speedy reintegration into society. In this context, Garofalo completely subordinated the rights of the individual with those of society and supported the legitimacy, appropriateness, and effectiveness of the death penalty to which he was very much in favour. In fact, in the face of plans for a new penal code, he denounces "a universal mitigation and proportion of all penalties" (Garofalo, 1885). In criminal procedure, he recommended against formalism and institutes of the guarantor, and especially against the principles of the adversarial process to which he contrasted the secret preliminary investigation, the extension of preventive detention, for an effective restriction of freedom. Garofalo also advised against the first attempts to link the reform of the criminal law to the social question and denied the usefulness of so-called "penal substitutes", i.e., the set of social instruments of crime prevention, which before Cesare Lombroso, then Enrico Ferri, were outlined in the new horizons of criminal law. The only legislation against the crime, as writes Garofalo, cannot refer that to a good police in the proper administration of justice, to indirectly promote public moral education, by preventing the growth of certain vicious habits that are the ordinary causes of crime (Garofalo, 1885). Finally, in the work there are some interesting pages that Garofalo dedicated to criminal courts drawing a category of magistrates entirely separate from that of the civil courts. It is necessary for "criminologists" judges, versed in criminal statistics and in prison discipline, able to perceive the psychological and anthropological characteristics that distinguish the criminals from one another.

\footnotetext{
${ }^{24}$ Taken from A.P. Senate XXVII Leg. 1924-1926. Sess. 1. Documents, 568-A: 2. "And then you will see whether it is acceptable that Italy, alone among the great nations of Europe, and with higher crime, must keep alive the largest and most ferocious killers".

${ }^{25}$ The work, after the first edition of 1885 , was published in 1890 in the second completely revised edition by the author in its French translation at the Parisian publisher Felix Alcan.

${ }^{26}$ Marchetti, P. (2009). Sentinels of evil. The nineteenth-century invention of the criminal enemy of society including legal naturalism, and psychiatric normativism. Quaderni Fiorentini for the history of modern legal thought, 1011. Milano: Giuffrè, 2009.

${ }^{27}$ Garofalo, R. (1914). Criminology, XXXII. Boston: Little Brown.

${ }^{28}$ Garofalo, R. (1893). Influences on Criminal Law of anthropology and criminal sociology. Positive School III: 774
} 


\section{About the Victims of Crime}

Garofalo believed that the State, having as main objective the protection of society, in order to repair the damage suffered by honest citizens cannot stick to a general condemnation of the perpetrators but must compel criminals with the fulfilment of the atonement of guilt with every energetic means ${ }^{29}$, by the quote, as the seizure of assets or signing of the mortgage on the office real estate, to execution, as the sale of assets in favour of the injured or the withholding of wages to be paid in a special cash out by the employers. Main aims of the State must be: the protection of law-abiding citizens against crimes and repair the damage suffered by them. About the victims of crime, Garofalo wrote: "Yet this class of people, to which every honest citizen will have the bad luck of belonging, would deserve, by the State, a benevolent look and a word of comfort. They would be entitled to greater sympathy that the class of delinquents, who now seem to be the main object of the solicitude of our legislators" (Garofalo, 1887). Garofalo complained, in fact, the lack of attention by the State to those who suffer for a crime, so that the victims of crime seemed to be condemned to a position of social exclusion. With regard to the issue of repair, Garofalo published in 1877 the work Repair to victims of crime, in 1891 he delivered a report to the 3rd National Congress of Florence legal titled "If and which measures they suggest to better compensate the victims of judicial errors", and published in Milan The compensation to crime victims. Through these works, Garofalo tried to expose more systematically his theory, showing justice and social utility of repair. The moral reparation, for Garofalo, therefore, is only a part of what should be given to the offended and their families. The financial repair must not be limited to compensation for material damage only, but also of the moral. Forcing the offender to repair the damage was the best means of repression because the more useful not only for the injured but also for the State, which could well reduce the prison budget. The society has to protect with the more energetic means the vast majority of normal men ${ }^{30}$. At the basis of criminal law, there must be the need of social defense and the objective responsibility of the offender, which varies depending on its danger and its unsuitability to the social environment. The criminal, as a bio-social individual, must be judged and punished for his actual degree of danger in relation to the basic need of the existing social order defense (Garofalo, 1885) ${ }^{31}$. Through the repair by the offender, the offended, you must define a victim according to Garofalo, would be able to regain stability and security in their emotions and in their own lives. The victim may also be able to gradually overcome the feelings of revenge and resentment towards the offender, and the distrust of the authority would have to protect it. With the writing Against the current! Thoughts on the proposed abolition of the death penalty in the project of the Italian penal code, Garofalo said that the progress of anthropology, destroying the utopias of correctional school, had shown that the phrase ${ }^{29}$ Garofalo, R. (1887). Repair to the victims of the crime, VII-VIII. Torino: F.lli Bocca Editori. ${ }^{30}$ Garofalo, R. (1888). Against the current!, 47. Napoli: E. Anfossi.

${ }^{31}$ This theoretical approach is formulated by Lombroso, C. 1876. L' Uomo delinquente. Milano: Hoepli. See also Veneziani, P. (2000). Motivi e colpevolezza, 50. Torino: Giappichelli. 
"beast in human face" was not a popular metaphor, but a fact confirmed through scientific observation, so the reasons for the retention of the death penalty were to be found in anthropology and in criminal psychology. Everyone has the right to live in society because it's absolutely necessary, but cannot claim this right when his criminal conduct undermines the life of society (Garofalo, 1885) ${ }^{32}$. The crime is "the effect of psychic anomalies, sedimented habits, unhealthy environments", which must be fought with a penalty whose sole purpose is the elimination of evil, adapted to different types of offender: born, instinctive and accidental. The individual utterly devoid of moral sense, that of justice and feelings of pity, will be unable to adapt to social life, and therefore must be suppressed by applying the death penalty. The jurists however, meet this vital need by presenting projects of new codes that abolish almost all the means of elimination of the crime, and not oppose another levee to delinquency that hospitality in the state houses, where the criminals are entitled to bread and idleness, and whence they will come back to haunt the society and perpetuate the degenerate race (Garofalo, 1887).

\section{5. "Journal for the Abolition of the Death Penalty"}

At the time of Italian unification, in 1861, the laws of all the pre-unitary States provided for the death penalty except for the Grand Duchy of Tuscany, where the Grand Duke Peter Leopold welcomed the idea of Beccaria to replace capital punishment with imprisonment ${ }^{33}$. The Chamber of Deputies resolved the thorny issue with a lively debate, after which the House voted, on March 13, 1865, the end of the death penalty for common law offenses. The death penalty justified by the legal Italian had found a tough opponent in Carlo Cattaneo, for which legitimize it would have meant a barbarism of humanity and rationality of punishment as requested by the Enlightenment and, in particular, from Beccaria. The revolutionary ideas of Cattaneo were also shared by other two great lawyers of the time: Francesco Carrara and Pietro Ellero, who in 1861 founded the "Journal for the abolition of the death penalty", directed at raising public awareness on the need to eliminate capital punishment, considered absolutely illegitimate $^{34}$. The new element, stressed by the newspaper, was residing in the fact that for the first time the fight was faced not only by men of learning, but it included the most diverse social classes, who were unanimous in eliminating the death penalty for all, not for utilitarian reasons, but because it is contrary to the one foundation of reason to punish, that is the principle of legal protection "wanted by the supreme law of order"35. The abolitionists joined Guerrazzi, Tommaseo, Carducci, Garibaldi and especially Pasquale Stanislao Mancini. The executions

\footnotetext{
${ }^{32}$ In society, the lack of the essential qualities of living transforms the need for social life in the opposite need, that is the breaking of all ties with the maladjusted individual. However, the lack of suitability exists only if the individual is completely devoid of moral sense, that is, the feelings of justice and mercy, because only thanks to them he will be able to adapt.

${ }^{33}$ Grand Duke Peter Leopold with the enactment of a new Penal Code in 1786, went down in history as the first sovereign in Europe to abolish not only the death penalty but even torture.

${ }^{34}$ Caravale, M. (2008). Pena senza morte, 70. Milano: Franco Angeli Editore.

${ }^{35} \mathrm{Mereu}, \mathrm{I}$. (2000). La morte come pena. Saggio sulla violenza legale, $141 \mathrm{ff}$. Roma: Donzelli Editore.
} 
ceased, thanks to the amnesty, in 1877, and for the next fifty years, Italy showed the world that you could live without the death penalty. The abolitionists fought with Mancini and Zanardelli, and with the support of lawyers and public opinion, led the House to vote, in November 28, 1888, the new Penal Code that abolished the death penalty for ordinary crimes. Fascism was to make back the Executioner in Italian country. Laws of 9 November 1926 reintroduced the death penalty for the attacks to the king and the Duce. Then, with the Rocco Code of 1931, the death penalty was expanded to common murders. However, it's to be remembered that the fascists were forced to realize their special tribunal because the Italian Judiciary was not available to adhere to their wishes, as it was German against the Nazi regime. The last executions took place in the spring of 1947 when three criminals named "Those of Villarbasse" were killed" ${ }^{36}$ Italy, along with Germany, abolished the death penalty immediately after the Second World War. The republican Constituent Assembly couldn't do otherwise than to abolish the death penalty, but did it with reserve, leaving it as an extreme hypothesis in Article 27, which read: "the death penalty is not permitted except in cases provided by military laws of war". Faith in the Executioner, however, dies hard. From the years of terrorism, and to the mafia massacres of 1992, in Italy, there were several attempts to reintroduce the death penalty using the state of internal war (or to use the death penalty to put Italy in a kind of military dictatorship in the name of the desire for vengeance of the populace). So they are not rare cases today where, in front of some particularly heinous crime, the media make of sensationalism and raise voices in favour of an impossible return of the scaffold. However, these attempts fail due to the Italian Constitution and the Europe Union. Europe has long been opposed to capital punishment and doesn't exist, even in theory, the possibility that it will allow a State within the European Union or the Council of Europe, to bring again the Executioner. Unlike the Universal Declaration of Human Rights of 1948, which makes no mention of the death penalty, the European Convention, in its Article 2, expressly provides for it, but this possibility has been increasingly limited and now, with the Thirteenth Protocol 2002, and with the explicit prohibition included in the draft European Constitution, the European continent is "death penalty free" (Giusti, 2009). In any case, although the European continent is "death penalty free", and the modern criminal law is generally constituted from its rejection of torture, in recent years, with the escalation of acts of terrorism and global tension, it seems to reoccur, as we have seen, the relationship between torture and right, and therefore it is necessary to keep under control the attempt to re-legalize torture.

\section{References}

A.P. Senate XXVII Leg., Sess. 1, 1924-1926, Documents.

Adams, J. (1856). The Works of John Adams. Boston, MA: Little, Brown.

Beccaria, C. (1965). Dei delitti e delle pene (Ed. by F. Venturi). Torino: Einaudi; Milano:

${ }^{36}$ See Giusti, C. (2009). Breve storia dell'abolizione della pena di morte in Italia.

http://www.osservatoriosullalegalità.org 
Edizione Nuovissima, 1764.

Bulletin "Foro Romano". 3-4, 2007, 665-666.

Caravale, M. (2008). Pena senza morte. Milano: Franco Angeli Editore.

Cattaneo, M. A. (1968). Freedom and Virtue in the Political Thinking of Robespierre. Milano: Editorial Cisalpino Institute.

Chinard, G. (1926). The Commonplace Book of Thomas Jefferson. Baltimore, MD: Johns Hopkins Press.

Cornell, S. (2004). A New Paradigm for the Second Amendment. Law and History Review, 22, 161-167. https://doi.org/10.2307/4141668

Frankenberg, G. (2008). Torture and Taboo. An Essay Comparing Paradigms of Organized Cruelty. The American Journal of Comparative of Law, 56, 403-422. https://doi.org/10.5131/ajcl.2007.0011

Funston, J. R. (1976). Cesare Beccaria and the American Founding Father. Italian Americana, 3, 72-92.

Garofalo, R. (1885). Criminology. Study on Crime, Its Causes and the Means of Repression (pp. 422-423). Torino: F.lli Bocca.

Garofalo, R. (1887). Repair to the Victims of the Crime (pp. VII-VIII). Torino: F.lli Bocca Editori.

Garofalo, R. (1888). Against the Current! (p. 47). Napoli: E. Anfossi.

Garofalo, R. (1893). Influences on Criminal Law of Anthropology and Criminal Sociology. Positive School, III, 774.

Garofalo, R. (1914). Criminology (Preface, p. XXXII). Boston, MA: Little Brown.

Giusti, C. (2009). Breve storia dell'abolizione della pena di morte in Italia. http://www.osservatoriosullalegalita.org/index.html

Grimm, D. (2004). Esgeht ums Prinzip. Frankfurter: Frankfurter Allgemeiner Zeitung.

Hegel, G. W. F. (1954). Elements of Philosophy of Right (p. 327). Roma: Laterza.

Ignatieff, M. (2004). The Lesser Evil. Political Ethics in an Age of Terror. Princeton, NJ: Princeton University Press.

Jefferson, T. (1904). The Writings of Thomas Jefferson (I, p. 67 ff., p. 218 ff). (Washington DC: Thomas Jefferson Memorial Association.

Kant, I. (1956). Political Writings and the History and Philosophy of Law (Ed. by G. Solari and G. Vidari, p. 522). Torino: Utet.

Kidder, F. (1870). History of the Boston Massacre (p. 232). Albany, NY: Joel Munsell.

La Torre, M. (2009). Derecho y fuerza. Jueces para la Democrazia, 66, 97-124.

La Torre, M. (2015). Amicizie Pericolose. Tortura e diritto. Filosofia del Diritto, 2, 271-282.

Lombroso, C. (1876). L'Uomo delinquente. Milano: Hoepli.

Lundberg, D., \& May, H. (1976). The Enlightened Reader in America. American Quarterly, 28, 262-293. https://doi.org/10.2307/2712353

Lutz, D. S. (1984). The Relative Influence of European Writers on Late Eighteenth Century American Political Thought. American Political Science Review, 78, 189-197. https://doi.org/10.2307/1961257

Maestro, M. (1973). A Pioneer for the Abolition of Capital Punishment: Cesare Beccaria. Journal of the History of Ideas, 34, 463-468. https://doi.org/10.2307/2708966

Marchetti, P. (2009). Sentinels of Evil. The Nineteenth-Century Invention of the Criminal Enemy of Society Including Legal Naturalism, and Psychiatric Normativism. In Qua- 
derni Fiorentini for the History of Modern Legal Thought (p. 1011). Milano: Giuffrè.

Mereu, I. (2000). La morte come pena. Saggio sulla violenza legale (p. $141 \mathrm{ff}$.$) . Roma:$ Donzelli Editori.

Rush, B. (1792). Considerations of the Injustice and Impolicy of Punishing Murder by Death (p. 3 ff.). Philadelphia, PA: Mathew Carey.

Sanfrancesco website. Violence and Firearms: The US Are Questioning. http://www.sanfrancescopatronoditalia.it/17717

Schopenhauer, A. (1999). The Art of Insulting (Ed. by F. Volpi, p. 27). Milano: Adelphi.

Tessitore, G. (2003). Fascismo e pena di morte (p. 75). Milano: Franco Angeli Editore.

Turnbull, R. J. (1797). A Visit to the Philadelphia Prison (p. 6 ff.). London: J. Philips \& Son.

Veneziani, P. (2000). Motivi e colpevolezza (p. 50). Torino: Giappichelli.

Venturi, F. (Ed.) (1786) "Reform of the Tuscan Criminal Law" of November 30 (p. 274).

Submit or recommend next manuscript to SCIRP and we will provide best service for you:

Accepting pre-submission inquiries through Email, Facebook, LinkedIn, Twitter, etc. A wide selection of journals (inclusive of 9 subjects, more than 200 journals)

Providing 24-hour high-quality service

User-friendly online submission system

Fair and swift peer-review system

Efficient typesetting and proofreading procedure

Display of the result of downloads and visits, as well as the number of cited articles

Maximum dissemination of your research work

Submit your manuscript at: http://papersubmission.scirp.org/

Or contact blr@scirp.org 